\title{
Persepsi Mahasiswa Berkebutuhan Khusus Terhadap Implementasi Model Dammri
}

\author{
Dewi Ekasari Kusumastuti, Imam Yuwono \\ Universitas Lambung Mangkurat \\ Email: dewi.kusumastuti@ulm.ac.id
}

\begin{abstract}
Abstrak: Penelitian ini bertujuan untuk memperoleh gambaran persepsi mahasiswa berkebutuhan khusus terhadap implementasi model DAMMRI. Metode penelitian yang digunakan adalah metode deskriptif dengan pendekatan kualiatif. Subjek pada penelitian ini adalah 1 orang mahasiswa tunadaksa dan 1 orang mahasiswa tunagrahita ringan semester V, penelitian di lakukan di program studi pendidikan khusus FKIP ULM Banjarmasin, pengumpulan data dilakukan dengan metode observasi, wawancara, dan dokumentasi. Hasil penelitian menunjukkan bahwa persepsi kedua subjek terhadap implementasi model DAMMRI sudah baik dan mereka cukup antusias dengan adanya model ini. Namun apabila dibandingkan persepsi antara keduanya diketahui bahwa persepsi DRA terhadap implementasi model DAMMRI lebih baik dibandingkan IH. Temuan yang diperoleh sekaligus juga sebagai masukan adalah IH masih belum memahami peran juru ketik pada saat implementasi model DAMMRI sehingga ke depannya perlu dilakukan sosialisasi terhadap keberadaan juru ketik di dalam kelas.

Kata Kunci : Persepsi Mahasiswa Berkebutuhan Khusus; Implementasi Model DAMMRI
\end{abstract}

\begin{abstract}
This study aims to obtain a picture of the perceptions of students with special needs towards the implementation of the DAMMRI model. The research method used is a descriptive method with a qualitative approach. The subjects in this study were 1 person with intellectual disabilities and 1 student with mild mental retardation semester $\mathrm{V}$, the research was conducted in a special education program FKIP ULM Banjarmasin, data collection was carried out by observation, interviews, and documentation. The results showed that the perception of the two subjects towards the implementation of the DAMMRI model was good and they were quite enthusiastic about the existence of this model. However, when compared to the perception between the two, it is known that the perception of DRA on the implementation of the DAMMRI model is better than IH. The findings obtained at the same time as input is that IH still does not understand the role of typists when implementing the DAMMRI model so that in the future it is necessary to socialize the existence of typists in the classroom.
\end{abstract}

Keyword: Perception of Students with Special Needs; Implementation of the DAMMRI Model

\section{PENDAHULUAN}

Terdapat dua problematika besar yang sedang dihadapi oleh dunia pendidikan saat ini yaitu: (1) pertambahan jumlah anak yang tereklusikan (terabaikan) dari partisipasi pendidikan semakin banyak, (2) Pendidikan di sekolah masih belum memberi keuntungan kepada semua anak. Artinya, kebutuhan belajar anak secara individual belum dapat dipenuhi. Sekolah lebih menekankan pada pencapaian akademik dari pada mengembangkan anak sebagai individu mencapai perkembangan optimal. Untuk mengatasi dua problematika itu maka secara internasional terjadi pergeseran paradigma pendidikan dari pendidikan yang berifat konvensional (ekslusif) ke pendidikan yang menjangkau semua anak yang bersifat inklusif termasuk peserta didik berkebutuhan khusus.

Pendidikan inklusi merupakan sebuah pendekatan yang berusaha mentransformasikan sistem pendidikan dengan meniadakan hambatan-hambatan yang dapat menghalangi setiap siswa untuk berpartisipasi penuh dalam pendidikan (Latif, dkk, 2013). Dalam konteks ini, peserta didik berkebutuhan khusus yang dimaksud adalah mahasiswa dengan hambatan fisik dan motorik atausering disebut mahasiswa tunadaksa. Selainitujuga, mencakup mahasiswa dengan hambatan intelektual atau yang juga sering dikenal dengan mahasiswa tunagrahita. Seperti yang telah diketahui, mahasiswa tunadaksa mengalami hambatan pada otot, tulang, dan sendi. Meskipun demikian ia tetap membutuhkan pendidikan yang mampu mengoptimalkan potensi yang dimiliki. Hallahan dan Kauffman (1994) menyampaikan bahwa anak yang mengalami physical disabilities (ketidakmampuan fisik) adalah mereka yang juga mengalami keterbatasan fisik atau masalah kesehatan yang mengganggu kehadirannya di sekolah atau saat belajar sehingga layanan khusus, pelatihan, peralatan, bahan, atau fasilitas yang sesuai sangat diperlukan. Oleh karena itu layanan pendidikan yang tersedia bagi siswa tunadaksa perlu memperhatikan beberapa prinsip pendidikan bagi tunadaksa Pradipta, dkk 2018). 
Berdasarkan kondisi dari mahasiswa tunadaksa, secara khusus prinsip pembelajaran bagi mereka ada 2, yaitu prinsip multisensori dan prinsip individualisasi (Chori, 1995). Prinsip multisensori adalah prinsip pendidikan yang diberikan kepada mahasiswa tunadaksa dengan memanfaatkan seluruh sensori yang dimilikinya, supaya stimulus yang tidak bisa diterima oleh anak dapat digantikan dengan anggota tubuh lain yang masih berfungsi dengan baik. Prinsip individualisasi adalah prinsip pendidikan yang diberikan kepada mahasiswa tunadaksa berdasarkan kemampuan masing-masing anak.

Lain halnya dengan Mahasiswa dengan hambatan intelektual atau mahasiswa tunagrahita digambarkan dengan suatu kondisi yang terlambat dan terbatasnya perkembangan kecerdasan seseorang sedemikian rupa jika dibandingkan dengan rata-rata kecerdasan anak pada umumnya (Chasanah \& Pradipta 2019). Kondisi ini juga disertai dengan keterbatasan dalam fungsi beradaptasi dengan lingkungan dan hambatan dalam perilaku, berlangsung selama masa perkembangan sehingga membutuhkan layanan pendidikan khusus. (Wardani, 2016). Secara khusus prinsip pembelajaran bagi mahasiswa tunagrahita ada 5, yaitu: (1) Prinsip Skala Perkembangan Mental, yaitu: prinsip ini menekankan pada pemahaman guru mengenai usia kecerdasan anak tunagrahita. Dengan memahami usia ini guru dapat menentukan materi pelajaran yang sesuai dengan usia mental anak tunagrahita tersebut. Melalui prinsip ini pun dapat diketahui perbedaan antar individu, (2) Prinsip Kecepatan Motorik, yaitu: melalui prinsip ini anak tunagrahita dapat mempelajari sesuatu dengan melakukannya (Pradipta \& Dewantoro, 2019). Di samping itu, dapat melatih motorik anak terutama untuk gerakan yang kurang mereka kuasai, (3) Prinsip Keperagaan, yaitu: prinsip ini digunakan dalam mengajar anak tunagrahita mengingat keterbatasan anak dalam berpikir abstrak (Sari, dkk, 2020). Dalam menentukan alat peraga hendaknya tidak abstrak serta mampu menonjolkan materi yang diajarkan, (4) Prinsip Pengulangan, yaitu: salah satu karakteristik anak tunagrahita adalah mudah lupa mengenai apa yang dipelajarinya maka dalam mengajar mereka membutuhkan pengulanganpengulangan disertai contoh yang bervariasi, (5) Prinsip Individualisasi, yaitu: setiap individu tunagrahita memiliki karakteristik yang berbeda-beda, prinsip ini menekankan pada perbedaan karakteristik tersebut. Anak tunagrahita belajar sesuai daya tangkapnya masing-masing. Meskipun demikian mereka harus tetap belajar bersama-sama dengan teman-temannya satu kelas tanpa dipisahkan, hanya saja dalam proses pembelajaran kita harus memperhatikan daya tangkap yang beragam dari anak tunagrahita tersebut. (Wardani, 2016). Salah satu upaya menerapkan prinsip-prinsip tersebut adalah dengan menggunakan model pembelajaran yang sesuai. Model pembelajaran yang digunakan juga harus sesuai dengan pelajaran yang diberikan kepada mereka. Masalah dan tantangan belajar di Perguruan Tinggi bagi anak berkebutuhan khusus tentu lebih besar dibanding dengan kesulitan yang dihadapi mahasiswa reguler. Masalah dan tantangan tersebut pun terlihat dan dirasakan oleh mahasiswa tunadaksa dan tunagrahita di Program Studi Pendidikan Khusus FKIP ULM Banjarmasin, dalam pelaksanaan perkuliahan di kelas mahasiswa tunadaksa dan tunagrahita mengalami keterbatasan jika mengakses informasi dari dosen yang terlalu banyak dan bersifat abstrak tanpa bantuan visual dan praktek secara langsung.

Ristekdikti melalui dirjend Belmawa membuat sebuah program berupa hibah pengembangan inovasi model pembelajaran bagi mahasiswa berkebutuhan khusus sebagai salah satu upaya untuk mengatasi permasalahan dan tantangan tersebut. Dengan adanya peluang tersebut kami berkesempatan untuk mengembangkan beberapa model pembelajaran bagi mahasiswa berkebutuhan khusus, salah satunya adalah model DAMMRI yang dirancang dengan berdasar pada penggabungan prinsip-prinsip pembelajaran anak tunadaksa dan tunagrahita dengan harapan dapat memfasilitasi dan memudahkan mahasiswa tunadaksa dan tunagrahita dalam mengikuti kegiatan perkuliahan dikelas, khususnya untuk mata kuliah yang bersifat praktikum, serta meningkatkan partisipasi belajar mahasiswa tunadaksa dan tunagrahita dalam kegiatan perkuliahan di kelas. Ucapan terimakasih yang setinggitingginya kepada ristekdikti dirjen Belmawa yang telah menyetujui dan mendanai inovasi model pembelajaran yang telah kami kembangkan. Dengan demikian, tujuan dari penelitian ini adalah untuk memperoleh gambaran persepsi mahasiswa berkebutuhan khusus terhadap implementasi model DAMMRI.

\section{METODE}

Metode yang digunakan dalam penelitian ini adalah metode deskriptif dengan pendekatan kualitatif. Subjek dalam penelitian ini adalah 1 orang mahasiswa tunadaksa dan 1 orang mahasiswa tunagrahita ringan semester V. Penelitian di lakukan di kelas pada program studi pendidikan khusus FKIP ULM Banjarmasin. Pengumpulan data dilakukan melalui pengisian angket pada google form yang diisi oleh mahasiswa tunadaksa dan mahasiswa tunagrahita dengan pendampingan volunteer.

\section{HASIL DAN PEMBAHASAN}

\section{Hasil}

Permasalahan yang dialami mahasiswa tunadaksa dan tunagrahita pada saat pelaksanaan perkuliahan pendidikan jasmani adaptif adalah keterbatasan mereka dalam mengakses informasi dari dosen yang terlalu 
Tabel 1. Sintaks penerapan model pembelajaran DAMMRI

\begin{tabular}{ll}
\hline $\begin{array}{l}\text { K o m p o n e n } \\
\text { Model } \\
\text { DAMMRI }\end{array}$ & $\begin{array}{l}\text { Makna Komponen } \\
\text { Model DAMMRI }\end{array}$ \\
\hline Demonstration & $\begin{array}{l}\text { Penyampaian materi perkuliahan } \\
\text { menggunakan alat peraga }\end{array}$ \\
Adroitness of & $\begin{array}{l}\text { Mempelajari sesuatu dengan } \\
\text { melakukannya }\end{array}$ \\
& $\begin{array}{l}\text { Melatih motorik terutama untuk } \\
\text { gerakan yang kurang dikuasai }\end{array}$ \\
Multisensory & $\begin{array}{l}\text { Penyampaian materi perkuliahan } \\
\text { dengan memanfatkan dan } \\
\text { mengembangkan indera-indera yang } \\
\text { ada dalam diri mahasiswa dengan } \\
\text { hambatan fisik dan motorik }\end{array}$ \\
Mental Development & $\begin{array}{l}\text { Pemahaman dosen mengenai usia } \\
\text { kecerdasan mahasiswa dengan } \\
\text { heale }\end{array}$ \\
hambatan intelektual & $\begin{array}{l}\text { Penyampaian materi perkuliahan } \\
\text { melalui pengulangan-pengula-ngan } \\
\text { disertai contoh yang bervariasi }\end{array}$ \\
Repetition & $\begin{array}{l}\text { Perkuliahan dalam satu ruangan } \\
\text { dengan kedalaman dan keluasan } \\
\text { materi yang berbeda }\end{array}$
\end{tabular}

1. Sintaks Implementasi Model DAMMRI

2. Dalam Pembelajaran Mata Kuliah Penjas Adaptif

Tahap Persiapan

1. Dosen dan Volunter melakukan asesmen dan menganalisis hasil asesmen mahasiswa intelektual dan hambatan fisik dan motorik. (Mental Development Scale)

2. Dosen berdiskusi dengan volunter untuk membuat RPS modifikasi dan melakukan analisis materi sesuai dengan kebutuhan mahasiswa intelektual dan hambatan fisik dan motorik. (Mental Development Scale)

3. Dosen menyusun modifikasi materi bagi mahasiswa intelektual dan hambatan fisik dan motorik dalam bentuk power point modifikasi dan menyerahkan ke mahasiswa melalui volunter paling lambat sehari sebelum perkuliahan. (Mental Development Scale)

4. Mempersiapkan media pembelajaran pendukung sesuai dengan kebutuhan dan materi perkuliahan yang akan disampaikan

Pelaksanaan Pembelajaran

1. Dosen mengatur posisi tempat duduk mahasiswa dengan hambatan intelektual dan hambatan fisik dan motorik bersebelahan dengan volunter dan juru ketik.

2. Dosen melakukan apersepsi terkait materi yang akan dibahas.

3. Dosen menyampaikan materi secara klasikal melalui PPT modifikasi, kemudian volunter mendampingi mahasiswa dengan hambatan intelektual dan hambatan fisik motorik untuk menjelaskan batasan materi yang dipelajari. (Individualitation)

4. Dosen menginstruksikan kepada mahasiswa regular dan mahasiswa dengan hambatan intelektual dan hambatan fisik motorik untuk mempraktekkan materi yang telah dijelaskan dengan bantuan volunter dan menggunakan alat peraga yang telah disediakan (demonstration \& Adroitness of Motoric)

Penutup

1. Dosen melakukan umpan balik dengan bertanya pada mahasiswa terhadap materi yang telah diajarkan dan membuka kesempatan kepada seluruh mahasiswa termasuk mahasiswa berkebutuhan khusus untuk bertanya (Repetition).

2. Dosen dan mahasiswa bersama-sama menyimpulkan materi yang telah dibahas (Repetition)

banyak dan bersifat abstrak tanpa bantuan visual dan praktek secara langsung.

\section{Pembahasan}

Oleh karena itu, program intervensi atau penanganan yang dilakukan oleh dosen adalah implementasi inovasi model pembelajaran DAMMRI yang didasarkan pada penggabungan prinsip-prinsip pembelajaran bagi anak tunadaksa dan tunagrahita yang meliputi: (1) skala perkembangan mental, (2) kecepatan motorik, (3) keperagaan, (4) pengulangan, (5) individualisasi, (6) multisensori (banyak indra), (7) individualisasi. Berkaitan dengan penerapan prinsipprinsip tersebut, dalam pelaksanaan pembelajaran lebih menekankan pada modifikasi materi, aktifitas visual, serta demonstrasi. Adapun tahapan atau sintak penerapan inovasi pembelajaran model DAMMRI dapat dilihat pada tabel 1. Setelah pelaksanaan implementasi model DAMMRI pada perkuliahan pendidikan jasmani adaptif di kelas, penelitian ini bertujuan untuk mengetahui bagaimana persepsi mahasiswa berkebutuhan khusus terhadap implementasi model DAMMRI. Data penelitian diperoleh dari pengisian angket oleh mahasiswa tunadaksa dan mahasiswa tunagrahita dengan pendampingan volunteer pada google form. Adapun hasil dari penelitian ini dapat dilihat pada tabel 2 .

Berdasarkan hasil penelitian diatas dapat diketahui bahwa pada subjek pertama yaitu mahasiswa tunadaksa berinisial DRA menyatakan sangat setuju pada 17 pernyataan dan setuju pada 2 pernyataan. Sedangkan pada subjek kedua yaitu mahasiswa tunagrahita berinisial IH menyatakan sangat setuju 
pada 6 pernyataan, setuju pada 12 pernyataan, dan netral pada satu pernyataan. Dapat diketahui bahwa persepsi kedua subjek terhadap implementasi model DAMMRI sudah baik dan mereka cukup antusias dengan adanya model ini. Namun apabila dibandingkan persepsi antara keduanya diketahui bahwa persepsi DRA terhadap implementasi model DAMMRI lebih baik dibandingkan IH. Temuan yang diperoleh sekaligus juga sebagai masukan adalah $\mathrm{IH}$ masih belum memahami peran juru ketik pada saat implementasi model DAMMRI sehingga ke depannya perlu dilakukan sosialisasi terhadap keberadaan juru ketik di dalam kelas.

\section{KESIMPULAN DAN SARAN}

\section{Kesimpulan}

Implementasi model DAMMRI berdasarkan pada penggabungan prinsip-prinsip pembelajaran bagi anak tunagrahita dan tunadaksa yang meliputi (skala perkembangan mental, kecepatan motorik, keperagaan, pengulangan, individualisasi, multisensori (banyak indra), dan individualisasi) yang dalam pelaksanaan pembelajaran lebih menekankan pada modifikasi materi, aktifitas visual, serta demonstrasi.

Setelah pelaksanaan implementasi model DAMMRI pada perkuliahan pendidikan jasmani adaptif di kelas, diketahui bahwa persepsi kedua subjek terhadap implementasi model DAMMRI sudah baik dan mereka cukup antusias dengan adanya model ini. Namun apabila dibandingkan persepsi antara keduanya diketahui bahwa persepsi DRA terhadap implementasi model DAMMRI lebih baik dibandingkan IH.

\section{Saran}

Berdasarkan pengalaman yang dialami dalam melakukan penelitian dan dari hasil penelitian, maka peneliti dapat memberikan saran untuk menyempurnakan penelitian-penelitian selanjutnya. Wilayah pengambilan responden penelitian ini hanya terbatas pada lokasi tertentu, sehingga untuk penelitian selanjutnya diharapkan dapat memperluas wilayah peneltian. Sehingga dapat memperoleh hasil secara representatif dari berbagai tipe maupun wilayah perguruan tinggi lainnya.

\section{DAFTAR PUSTAKA}

Chasanah, N. U., \& Pradipta, R. F. Pengaruh Penggunaan Media Sempoa Geometri pada Kemampuan Berhitung Tunagrahita.

Chori, A.Salim. 1995. Ortopedagogik Anak Tunadaksa. Departemen Pendidikan dan Kebudayaan Dirjen Pendidikan Tinggi Proyek Pendidikan Tenaga Guru

Hallahan, Daniel P., \& Kauffman, James M. 1994. Exceptional Children.Needham Heights: Allyn \& Bacon

Latif, Mukhtar dkk. 2013. Pendidikan Anak Usia Dini. Jakarta: Kencana

Pradipta, R. F., Dewantoro, D. A., \& Ummah, U. S. (2018, October). Full Day School Implementation in Special Junior High School. In 3rd International Conference on Educational Management and Administration (CoEMA 2018). Atlantis Press.

Pradipta, R. F., \& Dewantoro, D. A. (2019). Origami and Fine Motoric Ability of Intellectual Disabiliy Students. International Journal of Innovation, 5(5), 531-545.

Sari, G. S., Huda, A., \& Kustiawan, U. (2020). Media Quiet Book untuk Meningkatkan Keterampilan Merawat Luka Ringan Anak Tunagrahita. Jurnal ORTOPEDAGOGIA, 5(2), 81-84.

Wardani, I.G.A.K, dkk. 2016. Pengantar Pendidikan Anak Berkebutuhan Khusus. Tangerang Selatan: Universitas Terbuka 